\title{
The right of the citizens belonging to national minorities to education at universities in the Slovak Republic
}

\author{
doc. JUDr. Klaudia MARCZYOVÁ, PhD. \\ Mgr. Marián PIVÁČEK
}

\begin{abstract}
The authors of the article focus on fundamental rights and freedoms, and in particular on the current issue of the right to education and minorities in Slovakia. They draw on the essence and significance of the right to education as one of the most important rights. They elaborate on the related issues in the context of the right being asserted by the citizens of national minorities and place special emphasis on the right to education in the language of a national minority at a university. They introduce relevant legislation related to the subject matter, and point out the real possibilities of education and training of national minority citizens at universities in the Slovak Republic.
\end{abstract}

\section{Keywords}

national minority, Charter, right to education, education system, universities, legislation, constitution

\section{Introduction}

The status of national minorities, the guarantee of fundamental rights and freedoms of persons belonging to national minorities remain an up-to-date issue and require due attention to be paid in all areas. The priority area is definitely the legal area and the incorporation of the rights of national minorities and ethnic groups into the legislation of relevant states. The legislation contains the commitments following from international treaties and covenants pertaining to the subject area not only today. As J. Drgonec says: "The protection of national minorities settled in the territory of the Czechoslovak state was founded by the international treaties on the establishment of relations in Europe after the First World War as a precondition to the creation and existence of the state of the Czechoslovak Republic". ${ }^{1}$

1 DRGONEC, Ján: Ústava Slovenskej republiky: teória a prax, Bratislava 2015, 745. 
The Slovak Republic is, just like other European states, a multi-ethnic and multicultural country, and as a democratic and legal state it acknowledges, respects and protects fundamental rights and freedoms, including the rights of national minorities and ethnic groups. ${ }^{2}$ One of the rights granted to citizens belonging to a national minority is the right to education in their mother tongue, which shall be discussed further.

\section{Education of national minorities from the historical aspect}

After the dissolution of Austria-Hungary, the question of the newly-created Czechoslovak Republic was not sorted out definitely. For the international recognition of the Czechoslovak Republic, the negotiations at the Versailles Peace Conference in 1919 were of great importance; this has been known as the Versailles system. The talks at the peace conference brought the signing of the treaty with Austria in Saint-Germain-en-Laye on 10 September 1919. On that day, the representatives of the Czechoslovak Republic signed one more document - the Small Treaty of Saint-Germain that stipulated the commitments of the Czechoslovak Republic including the protection of national minorities. These commitments became a part of the Constitution of the Czechoslovak Republic. ${ }^{3}$ The Small Treaty of SaintGermain was published under Act No. 508/192, where Article 9 stipulated that regarding public education in towns and districts with a significant number of Czechoslovak citizens speaking a language other than Czech, the Czechoslovak government would provide adequate opportunities to guarantee education in their mother tongue. It would also arrange for the members of ethnic minorities to have the right to found, manage and control, at their expense, philanthropic, religious, social and educational institutions and schools where their mother tongue would be used and to hold religious services in such language. In accordance with the Treaty of Saint-Germain the commitments were incorporated in the fundamental law - the Constitutional Charter of the Czechoslovak Republic (published as Act No. 121/1920) and the Principles of the Language Act (No. 122/1920), which were ratified on 29 February 1920. The Constitutional Charter granted ethnic minorities the right to found and manage, at their expense, schools and other educational institutions where ethnic minorities had the right for an unlimited use of their mother tongue. It also stipulated the possibility of providing education to children of ethnic minorities in their mother tongue at public schools in those towns and districts with a significant part of Czechoslovak citizens belonging to religious, national and language minorities.

\section{Higher education at universities in Slovakia with the Hungarian language of instruction during the Czechoslovak Republic}

The education of members of the Hungarian national minority in the Hungarian language in Slovakia was available at several universities. The first university that provided lessons

2 NOVÁKOVÁ, Iveta: Aktuálne otázky národnostných menšín, in: Postavenie menšín pred a po vstupe štátu do Európskej únie: zborník príspevkov z vedeckej konferencie, Bratislava 2017, 69.

3 VESELÝ, Zdeněk: České politické dějiny: (od konce 18. do počátku 21. stoleti), Prague 2005, 123. 
for the Hungarian nationality in the Hungarian language was the Elisabethan University in Bratislava founded in 1912. Law was taught at the Academy of Law in Košice. According to S. Gabzdilová, "higher education study was provided by the evangelical Academy of Law and evangelical Academy of Theology in Prešov, Academy of Agriculture in Košice and the Mining and Forestry University in Banská Štiavnica". ${ }^{4}$

\section{Universities with the German language of instruction during the Czechoslovak Republic}

The university study for the members of the German minority in the German language was in a very different situation in Slovakia. University study in Slovakia during the Czechoslovak Republic virtually did not exist. When Slovak students belonging to the German minority wanted to get university education in their mother tongue, they had to study at German universities in Prague or Brno. ${ }^{5}$

\section{The right to education as a fundamental right}

The right to education is one of the fundamental rights and freedoms guaranteed by the Constitution of the Slovak Republic in Part 5 of Chapter II - Economic, social, and cultural rights. The purpose of the right is to provide education. The subject of the right is a natural person regardless of their citizenship. The difference between the legal status of a citizen and of an alien is only relevant to the particular condition of education provision - its financing. The Constitution of the Slovak Republic guarantees the citizens the right to free education at primary and secondary schools, and at universities depending on the possibilities of society and the abilities of the citizen. The guarantee of the fundamental right also follows from the international commitments of the Slovak Republic, whether it is the International Covenant on Economic, Social and Cultural Rights, or the Convention on the Rights of the Child. However, the legal status of citizens is different from the status of foreigners in terms of the expenses connected with the enjoyment of the right to education. In the case of foreign nationals, free education is not guaranteed at primary and secondary schools. "The Constitution in Article 42, Paragraph 2 grants the right to free education at universities, too. However, it is conditioned by the abilities of the citizen on the one hand and by the possibilities of society (mainly economic ones) on the other hand. It is not possible to derive a constitutional guarantee from the legislation, nor the existence of the fundamental (constitutional) right of a generally guaranteed free of charge university study, not even at public universities." ${ }^{6}$ Following from the wording of another provision of the Constitution of the Slovak Republic, there is no monopoly of state schools in the Slovak

4 GABZDILOVÁ, Soňa: Školský systém na Slovensku v medzivojnovej Československej republike (1918-1938), Košice 2014, 51.

5 Ibidem, 52.

6 Plenary of the Constitutional Court 3/2008. Ruling of 26 May 2010. Collection of rulings and resolutions of the Constitutional Court 2010, 122-123. 
Republic, but under the conditions stipulated by the law it is possible to establish schools other than state ones. With regard to an identical content of the legislation regulating the right to education in Article 33 of the Charter of Fundamental Rights and Freedoms we elaborate on it within the system of the Czech Republic. In accordance with the Charter, the right to education is granted to everyone, whether a foreign national, a homeless person, or an asylum-seeker. It is one of the priorities of the state, and its concept is also based on international law. Like the legislation of the Slovak Republic, also this context contains the regulation of one of the constitutional obligations - the obligation of compulsory education (following from the fundamental principle of the policy of a modern state). The given principle of the Charter implies the guarantee of free education at primary and secondary schools for the citizens of the Czech Republic. This was also declared by the Constitutional Court of the Czech Republic in its Decision No. 49/1994, where it was concluded that the right to free primary and secondary education is of an unconditional nature. ${ }^{7}$ The important principles contained in the Constitution of the Slovak Republic and the Charter include the principles of equality and non-discrimination. Therefore it is important to emphasize, with regard to the given right, the equality of education opportunities for all, the removal of obstacles to it and the respect for the educational needs of individuals. Consequently, we should also mention another decision of a constitutional court - the Constitutional Court of the Slovak Republic in its Decision No. II. ÚS 37/94 unambiguously states that the abilities of an applicant for a university study have to be tested in a legally identical way as those of other applicants for such study. Otherwise the Constitution of the Slovak Republic and the Charter define a different rule for university education - the right for free education is preconditioned by two factors - the abilities of the citizen and the possibilities of society.

\section{Right to education of the citizens of national minorities}

The Constitution of the Slovak Republic guarantees the right to education under Article 32, Paragraph 2, Letter a) consistent with the international documents - the European Charter for Regional or Minority Languages and the Framework Convention for the Protection of National Minorities. This right includes the right to education in the mother tongue as well as the rights of the citizens belonging to national minorities or ethnic groups. The purpose of the rights granted to national minorities and ethnic groups is the protection of the national identity as well as the creation of opportunities for education on a nationality principle using the mother tongue. "The purpose of the protection of national minorities according to the Framework Convention for the Protection of National Minorities is not the strengthening of the legal status of minority citizens at the expense of the status of the majority, but defining of the measures helping to preserve the status quo." 8 The right to education of national minorities has two main aspects. The first one means that persons belonging to national minorities should enjoy equal treatment; the second one includes the right of such persons

7 KLÍMA, Karel et al.: Komentář k Ústavě a Listině, Pilsen 2009, 1268.

8 DRGONEC, 748. 
to preserve and enhance such personal characteristics that make them different from the majority population (ethnic identity, language). In the Slovak Republic, there is one single education system which also includes the education and training of national minorities in their mother tongue and the study of their mother tongue. The education and training of national minorities is provided at preschools, primary schools, secondary schools, special schools and schools with the language of instruction or the minority language taught being Hungarian, Ukrainian, Ruthenian, German and Romany. The education and training of the Romany community and the children from the socially disadvantaged environment also takes place in schools and educational institutions. The education and training of children and pupils of national minorities is regulated mainly by the following legislation:

Act No. 245/2008 on Education and Training (the Education Act) as amended,

Act No. 596/2003 on State Administration in Education and Education Self-government as amended,

Act No. 597/2003 on Financing of Primary Schools, Secondary Schools and School Facilities as amended.

The system of primary and secondary education contains a concept of education and training of national minorities. The aim of the concept of education and training of national minorities is the creation of suitable conditions for equal education of all citizens of the Slovak Republic, the members of the constituent nation as well as all members of national minorities. The education in the languages of national minorities has a significant effect on the development and preservation of the multi-ethnic character of our country. The education is based on the principles of an equal access of all state citizens to education without any discrimination based on their race, skin colour, sex, language, faith and religion, nationality, ethnic background, social background, property, gender or other status. As Slovakia does not have an independent minority system, the exercise of the right to education in the mother tongue encounters certain problems. We have in mind that in our conditions it is not possible to get good education, or education of the same quality as in the official language, especially in the case of university education. Basically, at all levels of education, the Hungarian language of instruction may be found. The legislation enables children of national minorities to get education at all types of schools. That makes the education and training in the Hungarian language, and the schools and school facilities that provide them, an equal and inseparable part of the education and training system of the Slovak Republic. In the Slovak Republic there are 35 universities - 20 public universities, 3 state universities and 12 private schools. ${ }^{9}$ University education in several languages of national minorities is provided especially at the following schools:

- J. Selye University in Komárno (Univerzita J. Selyeho v Komárne),

- Comenius University in Bratislava (Univerzita Komenského v Bratislave),

- The University of Prešov (Prešovská univerzita v Prešove),

- The University of Ss. Cyril and Methodius in Trnava (Univerzita sv. Cyrila a Metoda $\checkmark$ Trnave),

9 Online: www.portalvs.sk. There are also foreign universities offering education in Slovakia. 
- Catholic University in Ružomberok (Katolícka univerzita v Ružomberku),

- Constantine the Philosopher University in Nitra (Univerzita Konštantína Filozofa v Nitre),

- Matej Bel University in Banská Bystrica (Univerzita Mateja Bela v Banskej Bystrici). ${ }^{10}$

The schools with the language of minorities being the language of instruction are an inseparable part of the education and training system in the Slovak Republic. The education achieved at these schools is equally valid as the education achieved at schools with the Slovak language of instruction. A specific feature of the study at a public or a state university in the Slovak Republic is the tuition fee in the full-time form of study at the above mentioned schools. The tuition payments may be characterised from two points of view. From the aspect of the language of the study, the study in a foreign language is paid. The study in the official language of the country or in the language of a minority is paid only in certain cases depending on the overall length of the study. In the cases of foreign language study programmes, the stipulation of the tuition amount is in the full competence of the university and the amount is not regulated. In the study programmes in a language of a national minority it needs to be distinguished whether the mission of the university or the faculty is to educate and train experts belonging to national minorities. Therefore, a study programme in the Hungarian or the German language may in some cases be provided free of charge, in other cases it may be paid depending on the mission of the university. From the aspect of the overall length of study, full-time students pay no tuition if the standard length of study has not been exceeded. ${ }^{11}$

\section{A list of Slovak universities with focus on the education of national minorities}

\section{J. Selye University in Komárno}

The university was established by the National Council of the Slovak Republic by Act No. $465 / 2003$ on the Establishment of J. Selye University in Komárno and on the amendment of Act No. 131/2002 on Universities as amended of 23 October 2003 effective as of 1 January 2004. The university is the only independent public university in Slovakia with the language of instruction being the language of a national minority, i.e. the Hungarian language, although according to the Act, the languages of instruction are Slovak, Hungarian etc.

The main mission of the university is to:

- create conditions for a university study especially for students of the Hungarian nationality in their mother language;

- increase the number of citizens of the Slovak Republic who are of Hungarian nationality having university education;

- create a qualification background for the increase of employment in the regions inhabited by the citizens of the Hungarian nationality;

10 Správa o postavení a právach príslušníkov národnostných menšín za rok 2015, Bratislava 2015, 67.

11 Online: https://www.minedu.sk/skolne-na-vysokych-skolach-v-sr/ (Downloaded 15 June 2017). 
- create conditions for the improvement of the education structure of the Hungarian minority living in the Slovak Republic towards the development of a highly educated intelligentsia that would become the drive of further development and engage in the life of international science and education;

- create conditions for the progression of experts from the Hungarian community in the field of scientific research;

- engage the researchers from the Hungarian community in the network of international scientific and research institutions;

- preserve and develop the cultural heritage of the Hungarian national minority living in the Slovak Republic;

- create conditions for the study of programmes for all degrees and in all forms in the Slovak language for applicants for the study at J. Selye University from the region inhabited by the Hungarian minority. ${ }^{12}$

\section{Comenius University in Bratislava}

It was founded in 1919 and has had a significant impact on the development of knowledge, science and culture in Slovakia. At the time of its establishment, it was the first university in the territory of Slovakia which provided the opportunity to get the highest level of education in the Slovak language. Since its establishment, the university has been at the forefront of the Slovak university education system and has become an internationally recognized centre of science and research. At the Faculty of Arts of Comenius University there is the Department of Slavic Studies that is achieving success. It was created in 1964 as the Department of Slavic and Indo-European Studies and its activities followed the activities of the Seminary for Slovak Studies, or later, of the Department for Church Slavic Language and Slavic Linguistics. One of the oldest university Slavic workplaces has existed since 1987 under a modified name as the Department of Slavic Studies. The initial form of a pedagogical study of Slavic languages was later substituted by translation and interpretation study, which today provides the study programmes on the Bulgarian language and culture, the Croatian language and culture and the Polish language and culture. A new study programme on Central-European Studies has been on offer for four years. The language of instruction in this programme for the Bachelor's degree is English, and it is compulsory for the students to choose from two languages of the Central-European area (Hungarian, German, Slovene, Polish). The Master's course continues in the Slovak language. Apart from these study programmes, the department also offers multiple language or culture oriented courses of Bulgarian, Croatian, Polish, Slovene, Serbian, Macedonian and Belorussian. At present, the Department of Slavic Studies offers the following study programmes:

- the Bulgarian language and culture

- the Croatian language and culture

- the Polish language and culture

12 Online: http://www.selyeuni.sk/documents/ 2016 Annual Report on the Activity and Economy of the JSU (Downloaded 15 June 2017). 
- Slavic studies

- Central-European studies ${ }^{13}$

The Bulgarian language and culture

The study of the Bulgarian language and culture is provided under the study specialization of translation and interpreting in combination with English, German, Croatian, Romanian or the Slovak language and culture. The study itself is broadly aimed at Slavic philology with special emphasis on acquiring the knowledge of normative grammar of Bulgarian, adequate vocabulary and basic knowledge of Bulgarian history, literature and culture.

The Croatian language and culture

The Croatian language and culture is also studied within the translation and interpreting specialization. The main aim of the study is to develop the ability to communicate independently in Croatian and gain theoretical knowledge of Croatian linguistics, literary science, culture, history and general background facts about Croatia.

The Polish language and culture

The study is also provided under the study specialization of translation and interpreting and is also broadly aimed at Slavic philology with special emphasis on acquiring the knowledge of normative grammar of Polish, adequate vocabulary and basic knowledge of the Polish history, literature and culture.

\section{The University of Prešov}

The University of Prešov is one of public universities and in the complex accreditation process it retained the status of a university and its place among universities. The study at the university offers a wide range of study programmes, many of them being unique in Slovakia. The long-term traditions at the University of Prešov include the scientific research as well as pedagogical work which focus on various specific problems of the region and national minorities. After 1997, new interdisciplinary work teams and scientific workplaces were created. These dealt systematically with social, ethnic and religious specifics of the North-Eastern Slovakia. Along with the faculties of the University of Prešov, university workplaces were founded with the focus on the above mentioned specific areas. These workplaces include the Centre of Languages and Cultures of National Minorities, which was established by the rector of the university on 1 December 2015 upon the consent of the Academic Senate of the University of Prešov. The Centre of Languages and Cultures of National Minorities was created by the merger of three originally independent university workplaces: the Institute of the Ruthenian Language and Culture, the Institute of Romany Studies and the Institute of the Hungarian Language and Culture. The centre has a specific mission in regional, national and transnational relations. It is built on ethnic and social specifics of the Eastern Slovak Region, which are studied and presented in national and

13 Online: https://fphil.uniba.sk/katedry-a-odborne-pracoviska/katedra-slovanskych-filologii/studium/ (Downloaded 18 June 2017). 
transnational relations. The Statute of the Centre of Languages and Cultures of National Minorities declares in Article 4 that "the education and training activities of the centre are based on the concept of its scientific and research activities, and the centre ensures the transfer of the research results into the teaching process. The centre participates in the education and training of teachers for the work at schools for national minorities in the Slovak Republic. It also prepares translators, interpreters and cultural workers for the purposes of intercultural communication between minorities and the majority nation".$^{14}$

The centre also participates in and prepares projects of other study programmes specializing in languages, literatures and cultures of minority groups of, mainly, Central Europe and in compliance with the requirements of the Slovak Republic and the European Union policy on nationalities. The centre comprises controlled scientific and educational institutions:

- The Institute of the Ruthenian Language and Culture,

- The Institute of the Hungarian Language and Culture,

- The Institute of Romany Studies and Culture.

The Institute of the Ruthenian Language and Culture

Since 1997/1998 with the support from the state, new primary schools teaching the Ruthenian language and later schools with Ruthenian as a language of instruction have been created in the Slovak Republic. This fact has required a prompt university training of teachers for the mentioned national minority schools. The planning of the schools was the task of the Institute of Nationality Studies and Foreign Languages of the University of Prešov. The institute was created for that purpose on 1 September 1998 as a workplace with a university-wide competence. An integral part of the institute was the Department of the Ruthenian Language and Culture, which was an institutional predecessor of the today's Institute of the Ruthenian Language and Culture established on March 2008. ${ }^{15}$

The Institute of Romany Studies and Culture

The institute was officially founded on 1 January 2011, however, the workplace went through some organizational changes; in the 1990s, the Institute of Nationality Studies and Foreign Languages was founded as a part of the University of Prešov, and it transformed later into a Research Centre. The university research into Romany issues goes further. It includes especially anthropological research, andragogy works, pedagogy works and cultural anthropology works of Dr. Alexander Mušinka. The aim of the workplace is to provide and coordinate scientific research oriented at a wide range of multidisciplinary scientific and specialist topics concerning the Romany ethnic group. The subjects of the research include issues of anthropology, history, geography, language, culture, political science, social issues etc. In terms of the territory it is primarily focused on the Roma in the Eastern part of Slovakia within the Central European context. ${ }^{16}$

14 Online: http://www.unipo.sk/public/media/24789/Statut-CJKNM.pdf (Downloaded 18 June 2017).

15 Online: http://www.unipo.sk/cjknm/hlavne-sekcie/urjk/o-institute/ (Downloaded 20 June 2017).

16 Online: http://www.unipo.sk/cjknm/hlavne-sekcie/urs/o-institute/ (Downloaded 21 June 2017). 
The Institute of the Hungarian Language and Culture

The institute started its operation at the University of Prešov in 2011. The main purpose of the establishment of the institute was to provide complex information on the language, literature and culture of the Hungarian nation and the Hungarian minority living in Slovakia from the past until the present. The second reason of its establishment was an external stimulus which was the current situation of the minorities. There are more than 130,000 citizens of the Slovak Republic of Hungarian nationality living in the Košice and Prešov Region who did not have an opportunity to get university education in their language in the territory. ${ }^{17}$ Educators from Slovakia and Hungary participate in the education of national minorities in the Eastern Slovak Region.

\section{University of Ss. Cyril and Methodius in Trnava}

The university was established under Act of the National Council of the Slovak Republic No. 201/1997 which came into effect on 1 August 1997. The aim of the University of Ss. Cyril and Methodius in Trnava is to train qualified experts who will be able to succeed in enhancing the Slovak culture, science and education in the context of the European and world cultural heritage, in the spirit of Christian and national ideals, and in accordance with the principles of democracy. The university provides the study at the Faculty of Arts in the specialisation of teaching for schools with a national minority language of instruction. ${ }^{18}$

\section{Constantine the Philosopher University in Nitra}

The founding of the university was approved by the National Council of the Slovak Republic on 23 October 1996. The inauguration ceremony took place on 13 February 1997. ${ }^{19}$ One part of Constantine the Philosopher University in Nitra is the Institute for Romany Studies which deals with the status and issues of the Roma in the Slovak Republic.

\section{The Institute for Romany Studies}

The institute was created as a unique university institution of a European or even of a global level in 1990 in response to the need for qualified staff that would be capable of improving the coexistence of the Roma and the majority population in Slovakia which had been burdened by economic, social, cultural and civilisation problems. Between 1990 and 2000 the Department of Romany Culture was a part of the Faculty of Education. Apart from the study programme Teaching the first stage of primary education specializing in the Romany culture, it also offered an accredited programme as a Master's degree course and Awareness raising work aimed at the Romany Community as a Bachelor's degree course in the later years. Thanks to the qualifications obtained, the graduates from the programmes found employment in expert or management positions at schools, specialist institutions as well as offices for education and training. The overall number presented 412 graduates

17 Online: http://www.unipo.sk/cjknm/hlavne-sekcie/umjk/o-ustave/ (Downloaded 20 June 2017).

18 Online: http://www.ucm.sk/sk/o-univerzite/ (Downloaded 21 June 2017).

19 Online: https://www.ukf.sk/o-univerzite/historia (Downloaded 21 June 2017). 
from the full-time or part-time Bachelor's and Master's courses. As professionals they now contribute to the improvement of the living conditions of the Roma in Slovakia. Since 2001 the Department of Romany Culture was a part of the Faculty of Social Sciences and Health Care. In 2005 the Department of Romany Culture changed its name to the Institute of Romany Studies. The main mission is to continue in the education of new Romany intelligentsia and of all others interested in the study programme regardless of their ethnic background. The vision of the Institute for Romany Studies is to retain its multicultural character so that students representing the majority and all national minorities could study at the institute. The primary aim of the education process has always been and will be education towards ethnic and nationality tolerance. ${ }^{20}$

\section{Catholic University in Ružomberok}

The founding charter of the Pedagogy Institute of St. Andrew in Ružomberok was signed on 29 June 1995 in Dolná Krupá. In 1996, the Academic Senate of the Trnava University created the Catechetic and Education Faculty of St. Andrew of Trnava University as a transformation of the Institute of Education of St. Andrew. In 1997 the Catechetic and Education Faculty was incorporated into the University of Žilina, and its statute, including the same rights of church supervision as were the rights for faculties of theology, was registered at the Ministry of Education of the Slovak Republic. The Catechetic and Education Faculty served as the basis for the foundation of Catholic University in Ružomberok. Act No. 167/2000 of 10 May 2000 on the establishment of Catholic University in Ružomberok stipulated the foundation on 1 July 2000 with two faculties: the Faculty of Education and the Faculty of Arts and Letters. The Faculty of Theology located in Košice was established on 1 July 2003; the fourth faculty the Faculty of Health started its work on 1 July 2005. Under Act No. 167/2000 Catholic University was founded as a non-state university, however, under Act No. 131/2002 on Higher Education Catholic University became a public university of a religious character on 1 April 2002. ${ }^{21}$ The Faculty of Education has a Department of Pre-school and Elementary Pedagogy for socially disadvantaged groups located in Levoča. The graduates of the course on preschool and elementary pedagogy are able to plan education and training activities in the environment of pre-school institutions, primary schools (especially the first stage) and school institutions for extra-classroom and extracurricular activities for children of pre-school age and pupils of the younger school age coming from a socially disadvantaged environment with a primary focus on specific groups of Romany children and pupils. ${ }^{22}$

\section{Matej Bel University in Banská Bystrica}

Matej Bel University was established on 1 July 1992 by merging the College of Economics of Services and Tourism in Banská Bystrica and the Pedagogical Faculty in Banská Bystrica,

20 Online: http://www.urs.fsvaz.ukf.sk/index.php?page=o-katedre (Downloaded 18 June 2017).

21 Online: http://www.ku.sk/index.php/ouniverzite/2013-04-18-13-11-20 (Downloaded 18 June 2017).

22 Online: http://www.ku.sk/images/dokumenty/pf/dokumenty/vyrocne_spravy/katedry/kpepszs_le/vs_2014_kpepszs. pdf (Downloaded 19 June 2017). 
as decreed by Act No. 139/1992 of the Slovak National Council dated 27 February 1992. The first university academic year started on 1 September 1992. Banská Bystrica has a long tradition of education and culture. In the $17^{\text {th }}$ century, a Jesuit grammar school was founded and soon followed by an Evangelical grammar school established in the same century. It was the latter where Matej Bel, who gave his name to the University, studied and later taught and held the position of the Rector.

Matej Bel (1684-1749) was the author of a large number of works about science, education, national history and geography, philosophy and religion. His postulates of the equal rights of nations, religious tolerance, of the integration of people and nations, of love of one's native country and his belief in the power of education and culture are still relevant.

In the academic year 1856-1857, a Teacher Training College was founded in Banská Bystrica, where thanks to then current Bishop Štefan Moyses, courses were provided not only in German and Latin, but also in Slovak. As early as that time, establishing a university in Banská Bystrica was considered. Because of the political situation of that time, these efforts failed to meet any understanding in the Austro-Hungarian Empire.

In the academic year 1949-1950, a branch of the Pedagogic Faculty of Slovak University in Bratislava was established in Banská Bystrica. It was not until 1954 that the first institution of higher education - the Higher Pedagogic School - started its activities. On 1 September 1964, the Pedagogic Faculty came into being. ${ }^{23}$

The structure of the Faculty of Arts of Matej Bel University in Banská Bystrica also includes the Department of Slavic Languages, which provides the education and training of highly qualified translators and interpreters from Polish and Russian, or teachers of the Russian language and literature who are very much desirable for the labour market.

\section{Table 1 A list of public colleges and universities in the Slovak Republic}

\begin{tabular}{|l|}
\hline The Academy of Arts in Banská Bystrica \\
\hline The University of Economics in Bratislava \\
\hline Catholic University in Ružomberok \\
\hline The University of Prešov in Prešov \\
\hline The Slovak University of Agriculture in Nitra \\
\hline The Slovak University of Technology in Bratislava \\
\hline Technical University in Košice \\
\hline Technical University in Zvolen \\
\hline Alexander Dubček University in Trenčín \\
\hline The University of Trnava in Trnava \\
\hline
\end{tabular}

23 Online: https://www.umb.sk/o-nas/informacie/o-univerzite/historia-umb.html (Downloaded 22 June 2017). 


\begin{tabular}{|l|}
\hline J. Selye University in Komárno \\
\hline Comenius University in Bratislava \\
\hline Constantine the Philosopher University in Nitra \\
\hline Matej Bel University in Banská Bystrica \\
\hline Pavol Jozef Šafárik University in Košice \\
\hline The University of Ss. Cyril and Methodius in Trnava \\
\hline The University of Veterinary Medicine and Pharmacy in Košice \\
\hline The Academy of Performing Arts in Bratislava \\
\hline The Academy of Fine Arts in Bratislava \\
\hline The University of Žilina in Žilina \\
\hline
\end{tabular}

Table 2 A list of state colleges and universities in the Slovak Republic

The Armed Forces Academy of General Milan Rastislav Štefánik in Liptovský Mikuláš

The Academy of the Police Force in Bratislava

Slovak Medical University in Bratislava

\section{Table 3 A list of private colleges and universities in the Slovak Republic}

Media Academy, a professional school for media and marketing communication in Bratislava

Bratislava International School of Liberal Arts

Ján Albrecht Music and Art Academy in Banská Štiavnica

Pan-European University

Central European College in Skalica

The University of Security Management in Košice

Danubius University

Dubnica Technology Institute in Dubnica nad Váhom

The College of Public Administration, Economics and Management in Bratislave

The College of Management in Trenčín

International Business College ISM in Prešov

St. Elisabeth College of Health and Social Work in Bratislava

Source: Zoznam vysokých škôl - Portál VŠ, online: https:// www.portalvs.sk/sk/ informacie-o-vysokychskolach $^{24}$

24 Table 1-3 compiled on the basis of information from https://www.portalvs.sk/sk/informacie-o-vysokych-skolach. 


\section{Conclusion}

Education and training plays an important role in dealing with many mutually overlapping and mutually strengthening problems. Education is also the only right explicitly included in the European Convention on Human Rights and is protected under Article 14 of the Convention on the Prohibition of Discrimination. The ability of Slovakia to effectively use and enhance its human potential is a precondition of not only economic and social, but also moral and cultural success. The state's policy in the area of education, science, sport and youth plays a key role if its aim is high quality of schools and excellent education. Although the education of national minorities is regulated by the valid legislation, in practice there are several problems that need to be tackled. It may be stated that the largest number of shortcomings exist especially in the level of university education. It is mostly available to the citizens of the Hungarian national minority. The biggest problems include the provision of a fully fledged education of the Romany community. The problem of educating the Romany community is a complex one. It is affected by so many aspects that it exceeds the issue of availability of university education. ${ }^{25}$ Recent years have brought only a slight progress in the education of the Roma in Slovakia. As a result, many of the problems remain unsolved and need to be dealt with urgently in order to reduce the difference between the academic results of the Romany and the non-Romany population therefore it is necessary to support public and private universities which provide education to future teachers of Romany children. The emphasis is on the possibility to use the Romany language in education. It is also important to respect the findings of experts in creating policies and taking measures in education and training of children and youth from the marginalized Romany communities.

\section{References}

DRGONEC, Ján: Ústava Slovenskej republiky: teória a prax, Bratislava 2015.

GABZDILOVÁ, Soňa: Školský systém na Slovensku v medzivojnovej Československej republike (1918-1938), Košice 2014.

História - Katolícka univerzita v Ružomberku, online: http://www.ku.sk/index.php/ ouniverzite/2013-04-18-13-11-20 (Downloaded 18 June 2017).

História UMB - Univerzita Mateja Bela v Banskej Bystrici, online: https://www.umb.sk/ o-nas/informacie/o-univerzite/historia-umb.html (Downloaded 22 June 2017).

História univerzity - Univerzita Konštantína Filozofa v Nitre, online: https://www.ukf.sk/ o-univerzite/historia (Downloaded 21 June 2017).

KLÍMA, Karel et al.: Komentář k Ústavě a Listině, Pilsen 2009.

NOVÁKOVÁ, Iveta: Aktuálne otázky národnostných menšín, in: Postavenie menšín pred a po vstupe štátu do Európskej únie: zborník príspevkov z vedeckej konferencie, Bratislava 2017, 69.

O inštitúte - Ústav rómskych štúdií, online: http://www.unipo.sk/cjknm/hlavne-sekcie/urs/ o-institute/ (Downloaded 21 June 2017).

25 Online: http://www.ibar-Ilp.eu/assets/files/WP06/WP6_National_case_study_Slovakia_(Slovakian_version).pdf (Downloaded 22 June 2017). 
O inštitúte - Ústav rusínskeho jazyka a kultúry, online: http://www.unipo.sk/cjknm/hlavnesekcie/urjk/o-institute/ (Downloaded 20 June 2017).

O univerzite - Univerzita sv. Cyrila a Metoda v Trnave, online: http://www.ucm.sk/sk/ o-univerzite/ (Downloaded 21 June 2017).

O ústave - Ústav mad'arského jazyka a kultúry, online: http://www.unipo.sk/cjknm/hlavnesekcie/umjk/o-ustave/ (Downloaded 20 June 2017).

Portál VŠ, online: www.portalvs.sk.

Správa o postavení a právach príslušníkov národnostných menšín za rok 2015, Bratislava 2015.

Školné na vysokých školách v SR - Ministerstvo školstva, vedy, výskumu a športu Slovenskej republiky, online: https://www.minedu.sk/skolne-na-vysokych-skolach-v-sr/ (Downloaded 15 June 2017).

Štatút Centra jazykov a kultúr národnostných menšín - Prešovská univerzita v Prešove, online: http://www.unipo.sk/public/media/24789/Statut-CJKNM.pdf (Downloaded 18 June 2017).

Štúdium - Katedra slovanských filológií, online: https://fphil.uniba.sk/katedry-a-odbornepracoviska/katedra-slovanskych-filologii/studium/ (Downloaded 18 June 2017).

Ústav romologických štúdií, online: http://www.urs.fsvaz.ukf.sk/index.php?page=o-katedre (Downloaded 18 June 2017).

VESELÝ, Zdeněk: České politické dějiny: (od konce 18. do počátku 21. stoleti), Prague 2005. Výročná správa Katolíckej univerzity v Ružomberku, Pedagogickej fakulty, Katedry predškolskej a elementárnej pedagogiky sociálne znevýhodnených skupín za rok 2014, online: http://www.ku.sk/images/dokumenty/pf/dokumenty/vyrocne_spravy/katedry/ kpepszs_le/vs_2014_kpepszs.pdf (Downloaded 19 June 2017).

WP6 - Quality and Access - National study - Slovakian version 2011, online: http://www. ibar-Ilp.eu/assets/files/WP06/WP6_National_case_study_Slovakia_(Slovakian_version). pdf (Downloaded 22 June 2017).

Zoznam vysokých škôl - Portál VŠ, online: https://www.portalvs.sk/sk/informacieo-vysokych-skolach.

\section{Authors}

doc. JUDr. Klaudia Marczyová, PhD.

Katedra verejnoprávnych vied, Akadémia Policajného zboru v Bratislave

Department of Public Law, Academy of the Police Force in Bratislava

Sklabinská 1, 83517 Bratislava, Slovak Republic

klaudia.marczyova@minv.sk

Mgr. Marián Piváček

Katedra verejnoprávnych vied, Akadémia Policajného zboru v Bratislave

Department of Public Law, Academy of the Police Force in Bratislava

Sklabinská 1, 83517 Bratislava, Slovak Republic

marian.pivacek@minv.sk 